\title{
Implication of cyst morphology to dinoflagellate taxonomy
}

\author{
KAZUMI MATSUOKA \\ Laboratory of Coastal Environmental Sciences, Faculty of Fisheries, Nagasaki University \\ (kazu-mtk@net.nagasaki-u.ac.jp), Nagasaki, 852-8521, Japan
}

\begin{abstract}
SUMMARY: A part of modern dinoflagellates produce resting cysts. Morphology of such cysts is rather simple and different from that of motile vegetative cells. For this reason, two independent classification systems, one for motile forms and the other for resting cysts are developed independently. For understanding the evolution of dinoflagellates, we should unite these two systems. Important characters for dinoflagellate cyst identification are the shape of the cyst body and its ornamentation, wall structure and colour, and the type of aperture or archeopyle. The archeopyle is subdivided into three major groups; saphopylic, theropylic and cryptopylic types. In general, the first two types are developed in thecate peridiniales and gonyaulacales, and the last type is mainly formed in athecate gymnodiniales cysts. Observations of archeopyle types and wall composition in modern cysts have shown these features to be in dinoflagellate taxonomy. In the genus Protoperidinium, another new subgenus should be established for species having a combination apical archeopyle corresponding to three apical plates. Alexandrium tamarense has a chasmic archeopyle, but it is not clear in many cases. It may be the result of diminishing the opening on the cyst surface after gemination because of its thin and flexible cyst wall.
\end{abstract}

\section{KEY WORDS: dinoflagellate cyst, taxonomy, archeopyle, Alexandrium, Gymnodinium catenatum}

\section{INTRODUCTION}

More than 80 marine and 15 freshwater species of modern dinoflagellates are known to produce resting cysts. In these species, more than 16 species have been known to cause a red tide and seven species to be toxic 1). The term "cyst" is adopted for non-motile cell that lacks flagella and ability of movement. Sarjeant et al. ${ }^{2)}$ elucidated the ecological requirement for encystment as follows: adverse climatic conditions, feeding, decline in nutrient supply, a refuge from predation, reproductive process (asexual or sexual), and dispersion. Among these reasons, non-motile cells produced by asexual or sexual reproduction processes are significant and important for the dinoflagellate cyst study ${ }^{3}$.

The important morphological characters for identification of dinoflagellate cysts are the shape of the cyst body and its omamentation, wall structure and colour, and the type of aperture or archeopyle through which germinating cells leave the cyst. The archeopyle type can be a very useful character in determining the higher classification rank (genus and family) of cyst species.

However, since cysts possess no archeopyle before excystment, it is impossible to use this feature for routine identification. In comparison to the morphology of motile forms, cysts usually have a relatively simple, mostly spherical to peridinioid shape. As a result, identification of cysts based on a single morphological character is not always reliable, and other characters are needed. Actually some fossil cyst terminology are not directly relevant to modern cysts, because most of these terms are applied to fossil cysts. Those who are interested in modem dinoflagellate cysts have to refer to the original description mainly given by paleontologists who used fossil cyst terminology. These terms are still useful not only for paleontologists but also modem planktologists. Fensome et al. ${ }^{4)}$ attemped to unify two different classification systems proposed by paleontologists for fossil cysts and by planktologists for modern motile forms. For purpose for consistency, this is an improvement in the description of both fossil and modern cyst forms.

In this paper, I will introduce a recent progress of modern dinoflagellate cyst taxonomy with several examples including harmful species, and briefly discuss the archeopyle type of Alexandrium tamarense through the gemination experiments.

\section{CLASSIFICATION OF ARCHEOPYLE}

The term "archeopyle" is defined by Evitt ${ }^{5)}$ as an excystment opening formed at the germination stage of dinoflagellate cysts. In modern dinoflagellate cysts, apical, intercalary, precingular, archeopyle types and combinations of these series have been recognized. However, it is not possible to use this definition for cysts of gymnodinialean species that are not covered 
with typical thecal plates at the motile stage. Matsuoka ${ }^{6}$ proposed new descriptive terms for the archeopyle of modem dinoflagellate cysts in both naked and thecate dinoflagellates, and divided them into saphopylic, theropylic and cryptopylic archeopyles.

\section{Saphopylic archeopyle}

Archeopyle sutures correspond to paraplate boundaries and the operculum. Part of the cyst wall corresponding to the archeopyle is always detached from the cyst body. The archeopyle type can be subdivided into either apical, intercalary, precingular, or a combination from one or more plate series (Fig. 1). Most modern cysts belonging to the Peridiniales and Gonyaulacales have this archeopyle type.

\section{Theropylic archeopyle}

Archeopyle sutures follow paraplate boundaries. The operculum is usually attached to the cyst. This caused by the incomplete development of archeopyle sutures on the cyst body. This archeopyle can also be subdivided into several types based on the position of the sutures (Fig. 2). Matsuoka ${ }^{7}$ showed a provisional subdivision for this archeopyle, but further careful examination is needed to confirm this observation. Modem cysts produced by diplopsalid and calciodinellid species have this archeopyle type.

\section{Cryptopylic archeopyle}

Archeopyle suture does not reflect any plate boundary. The operculum is detached or free from the cyst caused by the absence of thecal plates in motile forms. Some modem gymnodinialian and gonyaulacacean cysts have this archeopyle type. On the basis of the shape of opening, this archeopyle type is classified into two forms, either chasmic (slit-like opening) (Fig. 3) or tremic (hole-like opening) ${ }^{6}$. It is notable that some modern cysts do not show any distinct excystment aperture after germination, probably because of the fragile nature of the cyst wall. This archeopyle type includes most cysts of Alexandrium species, Peridinium faeroense, and Ensiculifera imariense.

\section{SIGNIFICANCE OF CYST MORPHOLOGY IN DINOFLAGELLATE TAXONOMY}

\section{The genus Protoperidinium}

Identification on round brawn cysts ( $=$ Brigantedinium sensu paleontological nomenclature) attributable to the genus Protoperidinium is very difficult, because of no other useful characters except for the shape of the archeopyle.
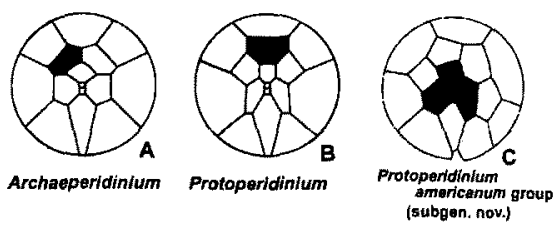

Fig. 1 Different archeopyle types recognized in modern Protoperidinium. A: Archeopyle corresponding to 2a plate of subgen. Archaeperidinium, B: Archeopyle corresponding to $2 \mathrm{a}$ plate of subgen. Protoperidinium, C: Archeopyle comesponding to 2', 3', 4' plates of Protoperidinium americanum (probably subgen. nov.).

Matsuoka $^{8)}$ pointed out that the morphological difference is in the hexagonal archeopyle shape of the cysts between the subgenera Archaeperidinium and Protoperidinium, because the former has only two anterior intercalary plates, and the latter has three. However, due to topological relationship, 2a plate of Archaeperidinium is hexagonal expanded laterally, and that of Protoperidinium is more ortho-hexagonal (Fig. 1). Recently, a different archeopyle type is recognized in the cyst of Protoperidinium americanum? ${ }^{9}$. The archeopyle of this species is composed of three apical plates (2', 3' and 4'; combination apical archeopyle). The wall structure of this species is also different from typical round brown cysts as it is two layered and cavate. A combination apical archopyle type is aiso found in fossil species, Islandinium minutum ${ }^{10)}$. This suggests that these motile forms should be classified into a different new subgenus of the genus Protoperidinium.

\section{Diplopsalid Group}

The marine diplopsalid group consists of approximately 10 genera including more than 15 species. Most of these species produce a resting cyst. Wall and Dale ${ }^{11)}$ investigated the cyst-theca relationship of some species of this genus. Subsequently more extensive studies on the cyst-theca relationship on several species of the Diplopsalis-group were made by Matsuoka ${ }^{7}$, Lewis 12) , and Dale et al. ${ }^{13)}$. Most of the cysts are round brown cysts being very similar to some of Protoperidinium cysts. Matsuoka ${ }^{7}$ noticed that the archeopyle of the dilplosalid cysts is different from those of Protoperidinium in always having an attached operculum named a theropylic (zig-zag slit-like suture) archeopyle. The development of the archeopyle sutures 
is different in different species (Fig. 2).

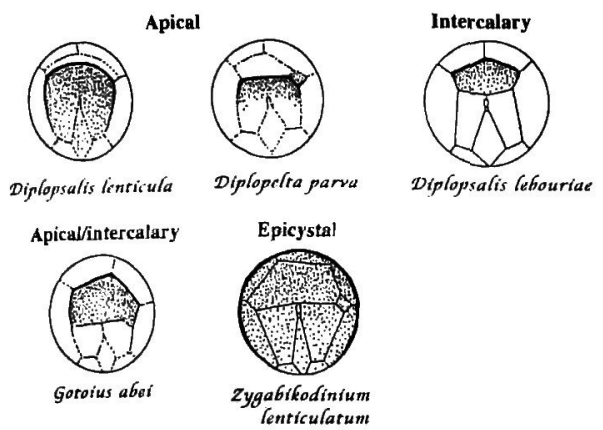

Fig. 2 Theropylic archeopyle types developed in modern diplopsalid groups.

\section{Gymnodinium catenatum and allid species}

Athecate Gymnodinium catenatum is a PSP causative dinoflagellate and can produce a resting cyst with reticulate ornaments on the surface and a chasmic archeopyle. Similar cysts have been found in Gymnodinium nolleri and G. microreticulatum (Fig. 3). These are very difficult to distinguish on each other except for cyst diameter and archeopyle type. According to Bolch et al. ${ }^{14)}$, the cysts $G$. catenatum and $G$. nolleri have a chasmic archeopyle along the paracingulum, but $G$. microreticulatum shows a chasmic slit running along the parasulcus.

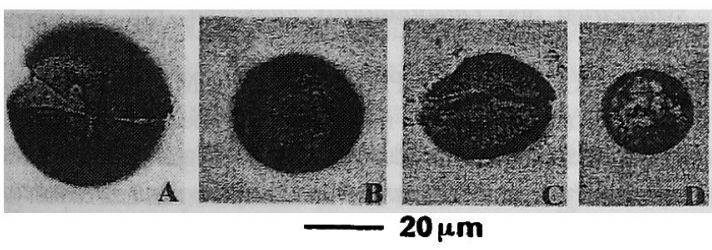

Fig. 3 Cysts with reticulate surface ornament in Gymnodinim catenatum and allied species. A: $G$. catenatum showing a chazmic archeopyle (surface sediments collected from Tsushima, Japan), B: G. nolleri-like cysts (surface sediments from Imari Bay, Japan), C: G. nollerï showing a chasmic archeopyle (fossil cyst in North Sea), D: G. microreticulatum (culture living specimen).

\section{Archeopyle and prossess variations in Lingulodinium polyedrum}

The cyst of Lingulodinium polyedrum is an example in showing wide morphological variations in process features and archeopyle type. The archeopyle of this species is a combination type including either several precingular plates or sometimes some anterior intercalary and apical plates. The process morphology is also variable from acuminate to bulbose in the distal extremities. Based on these features, several fossil forms were described as new species such as $L$. funginum, $L$. brevispinosum, and $L$. sadoense. However, after careful observations on the development of processes during cyst formation, these fossil species were recognized as a process variation in the cyst of $L$. polyedrum ${ }^{15}$.

\section{Archeopyle type of Alexandrium tamarense}

Using living cyst of $A$. tamarense collected from Kure Bay, Seto Inland Sea, Japan, the germination process was observed (Fig. 4). Before germination, most organelles including nucleus, chloroplasts and others are already developed within the hypnozygote (Fig. 4A). The juvenile cell, which is very flexible in shape comes out from one polar end (Fig. 4B, C). After gemination, the membrane covering the mesospore remains in the cyst cavity (Fig. 4D). No clear evidence for the archeopyle type is shown in the empty cyst (Fig. 4F, G). Most juvenile cells of $A$. tamarense germinated from one polar end, although gernination was rarely carried out also at the middle part of the cyst (Fig. 4E). However, well-preserved empty cysts rarely show a short slit at one polar end (Fig. 4H; Figs. $3 \mathrm{~L}$, M of Yamaguchi et al. ${ }^{16)}$. The archeopyle type of Alexandrium has been not yet fully understood except for $A$. pseudogonyaulax. The spherical cyst of this species has a clear slit-like archeopyle, but the position of this archeopyle is no yet fully understood ${ }^{17}$.

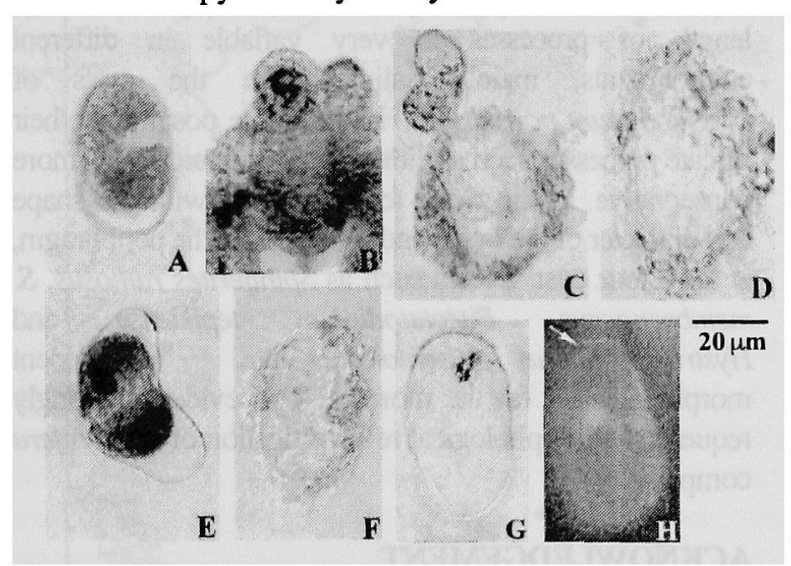

Fig. 4 Germinationn process from living cyst of Alexandrium tamarense, A: start for germination, B: juvenile cell coming out from one polar end, $C$ : juvenile cell just after escaping, D: empty cyst keeping mesospore membrane inside, E: juvenile cell coming out from the middle part of cyst, F\&G: empty cyst not showing any typical archeopyle, $\mathrm{H}$ : fossil empty cyst having a chasmic (short slit) archeopyle (lateral view). Materials A-H from the surface sediment of Kure Bay.

It is possibly a theropylic type. Zonneveld and Dale ${ }^{18)}$ mentioned that $A$ 
excavata (= $A$. tamarense), and $A$. catenella possess a rounded archeopyle as well as other cysts of Pyrophacus horologicum and Gyrodinium instriatum without any photograph. As previously mentioned, empty cysts of $A$. tamarense rarely have a chasmic archeopyle, however, most of them show no signs of an archeopyle. This might be the result of the thin, fragile and flexible characteristics of cyst wall of $A$. tamarense. At gernination, a rapture zone may be formed at one polar end and the juvenile cell is moved out from this space. After escaping the cell, the opening on the cyst surface may close smoothly. The difference in the archeopyle type between the cysts of $A$. pseudogoniaulax and $A$. tamarense is probably due to the different characteristics of the cyst wall.

\section{Heterosporous morphotypes in Gonyaulax spinifera group}

Earlier cyst-theca relationship studies revealed several different cyst morphotypes which germinated into the thecate species Gonyaulax spinifera ${ }^{11}$. These cysts were Bitectatodinium tepikiense, Ataxinodinium choanum, Nematosphaeropsis labyrinthes, Spiniferites elongatus, $S$. membranaceus, S. mirabilis and S. ramosus. Later, Dale ${ }^{3)}$ suggested that these cysts might be over-classified and reversely the thecate species might be under-classified, and called the thecate species as $G$. spinifera complex. Recently, Lewis et al. ${ }^{19,2)}$ carried out cyst incubation experiments on this group to clarify the problem. The length of processes is very variable in different environments, mainly salinity, like the cysts of Lingulodinium polyedrum. However, the position of their furcate processes such as either gonal or intergonal is more conservative. Using these features along with the shape and diameter of the cysts, and ornament of the periphragm, at least four cyst species such as Spiniferites ramosus, $S$. membranaceus, Bitectatodinium tepikiense and Hystrichosphaera bentorii are independent morphologically for the moment. This evidence strongly requests the morphological re-investigation of $G$. spinifera complex.

\section{ACKNOWLEDGEMENT}

I thank to Mr. K. Mizushima for his kind co-operation on the cyst incubation experiment of Alexandrium tamarense, and also to anonymous referees for useful comments.

\section{REFERENCES}

1. Matsuoka K, Fukuyo, Y Technical Guide for Modem dinoflagellate Cyst Study. WESTPAC-HAB/ WESTPACIOC, 2000; v + pp. 1-29.

2. Sarjeant WAS. Dinoflagellate cyst terminology: a discussion and proposals. Can. Jour. Bot. 1984; 60: 922-945.

3. Dale B. Dinoflagellate resting cyst. In: Fryxell GA (ed.) Survival Strategies of the Algae. Cambridge Univ. Press, 1983; pp. 69-144.

4. Fensome RA, Taylor FJR, Norris G, Sarjeant WAS, Wharton DI, Williams GL A classification of living and fossil dinoflagellates. Micropal. Spec. Publ. 1993; No.7: viii + pp. 1351.

5. Evitt WR. A discussion and proposals concerning fossil dinoflagellates, hystrichospheres and acritarchs. Nat. Acad. Sci. Proc. 1963; 49: 158-164 \& 298-302.

6. Matsuoka K Archeopyle structure of modem naked dinoflagellate cysts. Rev. Palaeobotan. Palynol. 1985; 45: 255-260.

7. Matsuoka K. Cyst-theca relationship in the Diplopsalid group (Peridiniales, Dinophyceae). Rev. Palaeobotan. Palynol. 1988; 56: 95-122.

8. Matsuoka K. Organic-walled dinoflagellate cysts from surface sediments of Akkeshi Bay and Lake Saroma, North Japan. Bull. Fac. Liberal Arts, Nagasaki Univ. 1987; 28: 35-128.

9. Lewis J, Dodge JD. The cyst-theca relationship of Protoperidinium americanum (Gran and Braarud) Balech. Hour. Micropalaeontol. 1987; 3: 113-121.

10. Head MJ, Harland R, Matthiessen J. Cold marine indicators of the Late Quaternary, including the new dinoflagellate cyst genus Islandinium. Jour. Quat. Sci. 2001; 16: 621-636.

11. Wall D, Dale B. Modern dinoflagellate cysts and evolution of the Peridiniales. Micropal. 1968; 14: 265-304.

12. Lewis J. The cyst-theca relationship of Oblea rotundata (Diplopsalidaceae, Dinophyceae). Bit. Phycol. Jour. 1990; 25 : 339-351.

13. Dale $B$, Montresor $M$, Zingone A, Zonneveld $K$. The cyst-motile stage relationships of the dinoflagellates Diplopelta symmetrica and Diplopsalopsis latipeltata. Eur. J. Phycol. 1993; 28: 129-137.

14. Bolch CIS, Negri AP, Hallegraeff GM. Gymnodinium microreticulatum sp. nov. (Dinophyceae): a naked, microreticulate cyst-producing dinoflagellate, distinct from Gymnodinium catenatum and Gymnodinium nolleri. Phycologia, 1999; 38: 301-313.

15. Kokinos JP, Anderson DM. Morphological development of resting cysts in cultures of the marine dinoflagellate Lingulodinium polyedrum ( = L. macherophorum). Palynology, 1995; 19: 143-166.

16. Yamaguchi M, Itakura S, Imai I, shida Y. A rapid and precise technique for enumeration of resting cysts of Alexandrium spp. (Dinophyceae) in natural sediments. Phycologia, 1995; 34: 207-214.

17. Yuki $\mathrm{K}$, .Kobayashi $\mathrm{S}$, Fukuyo $\mathrm{Y}$. Thecate and cyst forms of Alexandrium pseudogonyaulax (Dinophyceae) from Japanese coastal waters. Bull. Plank.Soc. Japan, 1996; 43: 46-50.

18. Zonneveld KAF, Dale B. The cyst-motile stage relationship of Protoperidinium monospinum (Paulsen) Zonneveld et Dale comb. nov. and Gonyaulax verior (Dinophyta, Dinopyceae) from the Oslo Fjord (Norway). Phycologia, 1994; 33: 359-368.

19. Lewis J, Eochon A, Ellegaard M, Mudie PJ, Harding I. The cyst-theca relationship of Bitectatodinium tepikense (Dinophyceae). Eur. J. Phycol. 2001; 36: 137-146.

20. Lewis J, Eochon A, Harding I. Preliminary observation of cyst-theca relationship in Spiniferites ramosus and Spiniferites membranaceus (Dinophyceae). Grana Suppl. 1999; 3: 1-12. 